\title{
MALAYSIAN ISLAMIC BANKS' EFFICIENCY: AN INTRA-BANK COMPARATIVE ANALYSIS OF ISLAMIC WINDOWS AND FULL-FLEDGED SUBSIDIARIES
}

\author{
Oladipupo Luqman Salami \\ University Technology Petronas \\ Adewale Abideen Adeyemi* \\ International Islamic University Malaysia
}

\begin{abstract}
This paper aims to fill an apparent dearth of empirical studies that compare the efficiency of Islamic banks in Malaysia during their operation as Islamic windows and later transformation to full-fledged Islamic banks. Data obtained from the annual financial reports of the sampled banks is analyzed using the Data Envelopment Analysis (DEA) via DEAP 2.1 software to assess both the technical and scale efficiency of the banks under sample. Results obtained indicate that the banks have improved over the years in terms of both scale and technical efficiency although the former takes prominence. In general, the banks were found to be more efficient as Islamic windows compared to being full-fledged subsidiaries. This augurs well for the current disposition where, as per the Islamic Financial Service Act 2013, Islamic banks in Malaysia may now operate as full-fledged banks from their hitherto Islamic banking window status.
\end{abstract}

Keywords: Scale Efficiency; Technical Efficiency; Islamic Window; Full-Fledged Banks.

\section{INTRODUCTION}

The banking industry is arguably the most regulated in any part of the world. This may be due to a plethora of reasons including the nature of their product - money, as well as their dual but conflicting obligations of liquidity and profitability to their depositors and shareholders respectively. As such, the need for banks to be efficient cannot be discounted. As rightly noted by Sufian (2007b), factors like globalisation, deregulation, financial innovation, etc and their consequential implication for financial stability advertises the need for banks to place performance upon themselves to sort through the often-impassioned arguments. Therefore, it is by design rather than happenstance that recently, numerous policies and academic attention has been placed on banks' efficiency (Hasan, Koetter, \& Wedow, 2009). However, in contrast

\& Corresponding author: Department of Finance, Kulliyyah of Economics and Management Sciences, International Islamic University Malaysia. Email: abidewale@iium.edu.my 
to the enormous researches on banking efficiency especially from the conventional perspective, a dearth of empirical studies from the Islamic banking perspective leaves a lacuna in the extant banking efficiency literature. This is rather ironical especially viewed against the backdrop of the monumental growth witnessed in the Islamic banking industry since the early 2000 (Laldin, 2008).

The Islamic banking system (IBS) is gradually becoming a global phenomenon and it is incontrovertible that Malaysia is one of the major hubs of the burgeoning industry. In Malaysia for instance, Islamic banking operates in two folds and under two different acts vis. the Islamic Financial Services Act 2013 and the Financial Services

Act 2014. As such, there are the full-fledged Islamic banks and conventional banks' Islamic window both of which have grown tremendously over the past years (Mokhtar, Abdullah, \& Al-Habshi, 2006). In a report by the Bank Negara Malaysia (Central Bank of Malaysia), Islamic banking sector has increased in total assets to RM 434.6 million 2011. This amounted to $22.4 \%$ of the total banking assets in the country as at the end of 2011 (Porter, 2012).

Arguably, the gradual development witnessed in the Islamic banking industry is reflected in its ability to withstand financial crisis. According to Derbel, Bouraoui \& Dammak (2011), the effect of the 2007/2008 global financial crisis on the Islamic banks is relatively mild compared to the conventional banks. This arouses interest on whether these banks are more efficient compared to their conventional counterparts. In this regard, numerous studies have compared both types of banks in terms of some efficiency benchmarks. For instance, studies like Bader, Mohamad, Ariff \& Hassan (2008) and Rafiuddin \& Alam (2012) found that the Islamic banks are more profit efficient while the conventional banks are more cost efficient. This may not be unexpected given that either bank's operational philosophy differs. ${ }^{1}$ However, an apparent lacuna is noted in lack of efficiency studies based on intra-banking system in which case, a full-fledged Islamic bank's efficiency is yet to be compared to its performance during operation as an Islamic window. This present study, therefore, aims to fill this gap in the context of the Malaysian banking industry.

The remaining of this paper is divided as follows. Immediately following this brief introduction is the literature review. This covers efficiency issues relating to Islamic banks, and the input and output variables used in the efficiency analysis of the study. Thereafter, the research methodology is discussed followed by the results of the analysis. The paper ends with a summary of major findings and the conclusion.

1 According to Rafiuddin \& Alam (2012), while the Islamic banks operate on a non-interest basis and have limited options on what type financial instruments they can trade in; their conventional counterparts operate an interest- based system and have more rooms to manoeuvre as per the types of instruments they can deal in. 


\section{LITERATURE REVIEW}

\subsection{Malaysian Islamic Banks Efficiency Studies}

As noted above a lot of studies have been conducted on bank efficiency and performance in the developed world. However, empirical studies on bank performance and efficiency in developing countries, especially emerging economies like Malaysia is relatively scarce. This is even more so in the context of Islamic banks. Most studies on Islamic banking efficiency compared Islamic banks with conventional banks. Samad (2009) was among the first researchers that conducted research on Malaysian Islamic banks efficiency. The study measured Islamic banks performance, in terms of profitability in comparison to their conventional counterparts using financial ratios as analysis tool. It compared efficiency of full-fledged Malaysian Islamic bank against conventional bank counterpart from 1992 to 1996. Samad (2009) established that conventional banks are more efficient in terms of managerial efficiency than the fully fledged Islamic bank. The study further examined productive efficiency and revealed that Islamic banks' average utilization rate is lower compared to conventional banks.

While still using financial ratios analysis, Samad (2004) also examined Malaysian Islamic banks efficiency performance over a longer period covering 1984 to 1997 . The study concluded that Islamic banks are more efficient compared to conventional banks in terms of liquidity and risk vulnerability. However, the study mentioned that Islamic banks are still under-performing due to lack of management skills which affected their growth during the period covered. Samad (2004) further adds that Islamic bank is less profitable compared to conventional banks, which prove that Islamic bank is less efficient. However, the productivity test by loan recovery measure reveals that Islamic banks are highly efficient and that bad debt as a percentage of shareholders' fund, loans and deposits also indicates high superiority over the conventional banks.

Sufian (2006) investigated Malaysian Islamic banking efficiency. The scope of the study spans three years from 2001 to 2004. The study used non-parametric Data Envelopment Analysis (DEA) methodology approach as analysis tool to compare Malaysian Islamic banks scale efficiency and technical efficiency. The study finds that Malaysian Islamic banks scale efficiency outweighs pure technical efficiency. The finding suggests that Malaysian Islamic banks are under-performing. It was further established that domestic Islamic banks are more technically efficient compared to foreign Islamic banks in Malaysia. The study revealed that inefficiency of foreign Islamic banks in Malaysia was as a result of more focus on scale rather than pure technical efficiency during the period.

Sufian (2007a) expanded the scope of the study by including some risk factors into his analysis. The study revealed that Islamic banks scale inefficiency was as result of pure technical inefficiency witnessed in the Malaysian Islamic banking industry during the scope of study. It was further established that foreign Islamic banks have higher technical efficiency compared to domestic Islamic banks in Malaysia. Sufian (2007a) further proved that Malaysian Islamic banks in year 2002 declined in efficiency. However, the banks have slightly recovered in 2003 and 2004 consecutively. Based on the DEA method adopted in the study, it was established 
that Malaysian domestic Islamic banks are more efficient compared to foreign Islamic banks in Malaysia, though with slight difference. The study proved that the cause of inefficiency in the Malaysian Islamic banks in general was as a result of wrong scale of operations.

In an empirical study conducted by Mokhtar, Abdullah \& Alhabshi (2008) on Malaysian Islamic banks for the period of 1997 - 2003, the findings of the study show that the efficiency of Islamic bank industry in the country has increased during the study period. However, that of conventional banks remained stagnant over the same time period. As such, the study established that conventional banks are still more efficient compared to the Islamic banks.

Rashwan (2010) examined the efficiency and profitability of both Islamic and conventional banks. The study focused on the pre and post 2008 financial turmoil by assessing if there are any major differences in the performance of the two systems. The study adopted MANOVA methodology to analyse the financial secondary data for the sample banks in the region. The study found there are statistically significant differences between the performances of the two banking systems in 2007 and 2009, while no statistically significant differences were obtained in 2008. The study revealed that Islamic banks outperform conventional banks in 2007 and conventional banks perform better than Islamic banks in 2009.

Abdul-Majid, Saal \& Battisti (2011) examined the efficiency of Malaysian commercial banks during the period of 1996 to 2002, and focuses on examining the impact of Islamic banking on its performance. The study revealed that Islamic banking is lesser in the input efficiency vis-à-vis cost efficiency. However, the full-fledged Islamic banks have higher productivity efficiency but this is not the same with conventional banks with Islamic window.

Apart from the studies reviewed above, nothing has been published that examined the efficiency of Islamic banks to assess their efficiency between when they were Islamic banking windows and when they transformed into full-fledged Islamic banks that are now full subsidiary of their parent banking group in Malaysia. In light of this knowledge gap, this study seeks to provide an empirical evidence to fill this apparent research gap vis-à-vis efficiency in the Malaysian Islamic banking industry.

\subsection{Approaches to Measure Bank Efficiency}

Generally, to establish the approach to assess the efficiency of banks, previous studies viewed banks from two main perspectives. The approaches are the intermediation and the production approach (Akhtar, 2010; Mohamad, Hassan, \& Bader, 2008; Sufian, 2007b; Sufian \& Haron, 2009).

The production approach on the one hand explains banking activities as production of services. This approach defines banks as manufacturer of loan to borrowers and deposit operators to depositors using capital and labour. This approach adopted traditional production factors, land, labour and capital as inputs used to generate desired outputs (Bader, et al., 2008). However, the production approach is said to be predominantly suitable for banks that involves in transaction of channelling the bulky deposits and money obtained from other financial organizations into 
loans and investments (Favero \& Papi, 1995). Moreover, interest expenses is not inclusive in the summation of total costs under the production approach, thus only operating costs are considered and output is determined by the number of accounts serviced rather than monetary values (Hassan, Mohamad, \& Bader, 2009).

The intermediation approach defines banks to be seen as a mediator of monetary transactions. As was recommended by (Sealey \& Lindley, 1977) this approach presents a bank as an intermediary that takes deposits from customers using labour and capital. These deposits are considered as inputs to the banks and are lent out to other customers that want to borrow money in form of loans and advances which are considered as output to the banks. Hence, this approach assumes banks to be a mediator between depositors and loan takers (Hassan, et al., 2009). Intermediation approach is arguably, the most globally accepted approach used to measure bank efficiency (Kwan, 2003). Berger \& Humphrey (1997) opined that this is because it includes interest expenses (interest paid to depositors). The interest expenses, often amounted to the half of the total costs of the banking operating expenses (Hassan, et al., 2009).

Though, some studies mentioned that production approach is more suitable to measuring bank's branches efficiency, reason been that at branch level customer documents are managed for the banks as a whole (Kwan, 2003). The intermediation approach is adopted by this study based on the following grounds: First, this study is assessing the whole banks efficiency and not branches. Secondly, the intermediation approach is widely adopted (Kwan 2003). Finally, the Islamic finance structure principle is based on profit sharing and asset-based financing where the parties involved in the transaction bear the losses or profits based on agreed ratio. These principles show importance of intermediary activities. Also other studies such as Hassan \& Hussein (2003), Hasan (2005) and Sufian (2006) just to mention but a few have also used this approach to measure Islamic banking efficiency.

\section{METHODOLOGY}

\subsection{Data}

This study assesses bank efficiency of domestic Islamic banks in Malaysia with focus on five domestic Islamic banks out of eight as listed by the Bank Negara Malaysia (Bank Negara, 2012). They are: Affin Islamic Bank, RHB Islamic bank, Public Islamic Bank, Hong Leong Islamic Bank, and May Bank Islamic. These five banks started as Islamic window and has since transformed into full-fledged Islamic banks as subsidiary of their parent conventional banks. As such, data were collected from these companies' annual reports covering the period from 2002-2011. As Islamic window, the banks report their Islamic banking operations under the note to the account. However, as a subsidiary, these banks operate as fully fledge Islamic banks and have their separate annual report different from their parent companies. Nearly all the banks have started to operate as full Islamic bank by 2008 (May Bank and Public Bank). Some started as early as 2005 - RHB Bank, Affin Bank and Hong Leong Bank started in 2006.

In spite of enormous literatures on bank efficiency, there is no format or agreed principles among scholars on what can be used as inputs and outputs variables in assessing efficiency 
of banks. One study's input variables might be used by other as output variables and vice versa (Mokhtar, et al., 2008). It is generally acceptable that the selections of variables in bank efficiency research drastically affect the outcome of the study (Sufian \& Noor, 2009). This issue intensified due to the fact that choosing variables are usually made difficult by the scarcity of data on relevant variables. Aside that, measuring costs as in banking in particular is difficult. This is because most of the financial activities are mutually produced and prices are usually allocated to group of financial services (Sufian \& Noor, 2009).

\subsection{Input and Output Variables}

To make choice of inputs and outputs variables, this study adopted the inputs and outputs variables as used by (Sufian \& Noor, 2009). This study collected data on two input variables and three output variables. The output variables are: total loans denoted by (Y1), which consist of loans to customers and other banks; income denoted by (Y2) which consist of income derived from investment of deposits and other proceeds from other Islamic banking activities; and the last is the investments denoted by (Y3) which consist of investment securities held for trading, investment securities available for sale, and investment securities held to mature. The input variables on the other hand are; total deposits denoted by (X1) which consist of deposit from individual customers, organizations and other banks; and capital denoted by (X2).

\subsection{Data Envelopment Analysis}

Data Envelopment Analysis, DEA is used as the tool of analysis. This study adopted Fare, (Färe, Grosskopf, \& Roos, 1998) approach to DEA to measure the efficiency of the banks, comparing their performance when they were operating as Islamic window and their performance as fullfledged Islamic banks. The Fare, et al., (1998) approach to DEA, employed output-oriented Malmquist Index (MI).

The MI is built using the DEA and this research used DEA software program developed by Coelli (1996) called DEAP version 2.1. The MI was chosen because of its desirable features that seem to be suitable for this research. This method does not require the normal norms such as profit optimization or cost reduction. This appears to be suitable for this research, because measuring cost minimization may prove difficult to measure efficiency. This is so given that the actual costs attributable to the banks when they are Islamic window are difficult to establish. For example, it would be difficult to measure other administrative expenses such as rental expenses, electricity bill, water rate and so on that is attributable to Islamic window.

Due to it features and merits, a lot of literatures have used the Malmquist productivity indexes in DEA. A few of those studies are Fare, Grosskopf, Norris \& Zhang (1994) which used this model to analyse the productivity comparison between countries, while Tauer \& Lordkipanidze (1999) and Koo \& Mao (1996) used this approach to examine economic sectors such as agricultural sector. (Alam \& Sickles, 1997) used this approach to examine productivity efficiency of airlines. Also (Calabrese, Campisi, \& Mancuso, 2002) used this approach to examine efficiency of telecommunications industry, while (Mlima \& Hjalmarsson, 2002) adopted this approach to measure production efficiency in banking and (Avkiran, 2001) used this approach to examine efficiency in the universities. 
The DEA approach used in this research expresses the output-based MI productivity between time periods $(\mathrm{t})$ and $(\mathrm{t}+1)$ which can be mathematical expressed into two equations as express by Fare et al (1989 cited in Wahab and Rahman, 2012 ).

$$
M_{o}\left(x^{t}, y^{t}, x^{t+1}, y^{t+1}\right)=\left(\frac{D_{o}^{t}\left(x^{t+1}, y^{t+1}\right) D_{o}^{t+1}\left(x^{t+1}, y^{t+1}\right)}{D_{o}^{t}\left(x^{t}, y^{t}\right) D_{o}^{t+1}\left(x^{t}, y^{t}\right)}\right)^{\frac{1}{2}}
$$

From equation (1) above, $D_{o}^{t}\left(x^{t+1}, y^{t+1}\right), \quad$ denote the distance between the period $(t+1)$ inspection to the period $t$ technology, where $\mathrm{x}$ and $\mathrm{y}$ represent input and output in that order. Equation (1) can be re-written following (Färe, et al., 1998) as follows:

$$
M_{o}\left(x^{t}, y^{t}, x^{t+1}, y^{t+1}\right)=\frac{D_{o}^{t+1}\left(x^{t+1}, y^{t+1}\right)}{D_{o}^{t}\left(x^{t}, y^{t}\right)} \times\left[\left(\frac{D_{o}^{t}\left(x^{t+1}, y^{t+1}\right)}{D_{o}^{t+1}\left(x^{t+1}, y^{t+1}\right)}\right)\left(\frac{D_{o}^{t}\left(x^{t}, y^{t}\right)}{D_{o}^{t+1}\left(x^{t}, y^{t}\right)}\right)\right]^{\frac{1}{2}}
$$

In equation (2) the first part of the ratio before multiplication measures the changes in relation to efficiency (that is the level of production changes year on year) between year's $t$ and $t+1$. The other part of the right hand side of the equation stand for arithmetic mean of the two ratios. It measures the technological changes (that is, changes in the frontier function itself) between the periods under examination $x^{t}$ and $x^{t+1}$. That is:

$$
\begin{gathered}
\text { Change in Efficiency }=\frac{D_{o}^{t+1}\left(x^{t+1}, y^{t+1}\right)}{D_{o}^{t}\left(x^{t}, y^{t}\right)} \\
\text { Technological Change }=\left[\left(\frac{D_{o}^{t}\left(x^{t+1}, y^{t+1}\right)}{D_{o}^{t+1}\left(x^{t+1}, y^{t+1}\right)}\right)\left(\frac{D_{o}^{t}\left(x^{t}, y^{t}\right)}{D_{o}^{t+1}\left(x^{t}, y^{t}\right)}\right)\right]
\end{gathered}
$$

Equation (3) examines the level at which the production procedure changes inputs into outputs (to meet up to the frontier) and equation (4) examines the development in technology. Improvement in the productivity yield in MI is represented by values that is more than 1 and if performance is declining over the year, it is represented by values less than 1 (Färe, et al., 1994). This explanation is used to explain the values of each of the element of the general Total Factor Productivity (TFP) directory. If the value of MI is greater than 1, then it is considered to be efficient indicating improvement in the productivity. Also if the value of the technological change element is more than 1 , it is referred to as efficient in the technology advancement.

From equation (4), distance is measured for each operative in each pair of duration by means of mathematical programming method. DEA is based on the assumption that $k=1$, where $k$ are organizations (in this case banks) that produce $\mathrm{m}=1$. M denote outputs $y_{k, m}^{t}$, whereas $\mathrm{N}=1$, where $\mathrm{N}$ denote inputs $x_{k, n}^{t}$, at every time period $\mathrm{t}=1, \mathrm{~T}$. 
In DEA, the indication of technology through Constant Returns to Scale (CRS) at every time period $t$ from the data can be expressed as:

$$
\begin{aligned}
& \mathrm{G}^{t}=\left[\left(x^{t}, y^{t}\right): y_{m}^{t} \leq \sum_{k=1}^{k} z_{k}^{t} y_{k, m}^{t}\right] m=1, \ldots ., M, \\
& \sum_{k=1}^{k} z_{k}^{t} x_{k, n}^{t} \leq x_{n}^{t}=1, \ldots, N, \\
& z_{k}^{t} \geq 0 \quad \mathrm{k}=1 \ldots \ldots \mathrm{K}
\end{aligned}
$$

In equation (5) $-Z_{k}^{t}$ stand for the weight on each exact cross-sectional examination. Using (Afriat, 1972) theory, to allow the Variable Returns to Scales (VRS), CRS have to be relaxed by adding the following constraint:

$$
\sum_{k=1}^{k} z_{k}^{t}=1(\mathrm{VRS})
$$

This research adopted Fare et al (1994) which spelled out the breakdown of the MI. The study categorized MI into the efficiency change component and scale efficiency change component. The efficiency change component measures CRS technology in relation to pure efficiency component. The scale efficiency change component on the other hand measures the variation in the difference connecting the VRS and CRS technology.

Pure efficiency element calculates the extent to which the banks can change inputs into outputs and the scale efficiency on the other side assesses the degree at which the banks can obtain benefit from returns to scale by increasing or decreasing in size towards achieving the best possible scale.

Therefore, under DEA approach to compose the MI productivity of any organization $k^{\prime}$ between $t$ and $t+1$, these distance functions have to be measured:

$$
D_{o}^{t}\left(x^{t}, y^{t}\right), D_{o}^{t+1}\left(x^{t}, y^{t}\right), D_{o}^{t}\left(x^{t+1}, y^{t+1}\right), D_{o}^{t+1}\left(x^{t+1}, y^{t+1}\right)
$$

These four distance functions can be equated with Farrell's output-based that measure technical efficiency. In DEA, Farrell's output-based measure the technical efficiency for every organization $\mathrm{k}^{\prime}=1, \ldots$, where $k$, can be stated as:

$$
\left[D_{o}^{t}\left(x_{k^{\prime}}^{t}, y_{k^{\prime}}^{t}\right)\right]^{-1}=\max \lambda^{k^{\prime}}
$$


Subject to

$$
\begin{aligned}
& \lambda^{k^{\prime}} y_{k, m}^{t+1} \leq \sum_{k=1}^{k} z_{k}^{t} y_{k, m}^{t} \quad m=1, \ldots, M, \\
& \sum_{k=1}^{k} z_{k}^{t} \quad x_{k, n}^{t} \leq x_{k^{\prime}, n}^{t+1}=1, \ldots, N, \\
& \sum_{k=1}^{k} z_{k}^{t}=1 \quad(\mathrm{VRS}) \\
& z_{k}^{t} \geq 0 \quad k=1, \ldots, K .
\end{aligned}
$$

The calculation of $D_{o}^{t+1}\left(x^{t+1}, y^{t+1}\right)$ is the same as Equation (8), anywhere $t+1$ is replaced by $t$. To calculate the MI, it also requires the construction of two mixed-distance functions that is calculated by evaluating the observation in one time period with the best practice frontier of another time period. The opposite of the mixed-distance function for observation $k^{\prime}$ can be obtained from:

Subject to

$$
\left[D_{o}^{t}\left(x_{k^{\prime}}^{t}, y_{k^{\prime}}^{t}\right)\right]^{-1}=\max \lambda^{\prime k^{\prime}}
$$

$$
\begin{aligned}
& \lambda^{k^{\prime}} y_{k, m}^{t+1} \leq \sum_{k=1}^{k} z_{k}^{t} y_{k, m}^{t} \quad m=1, \ldots, M, \\
& \sum_{k=1}^{k} z_{k}^{t} x_{k, n}^{t} \leq x_{k^{\prime}, n}^{t+1}=1, \ldots, N, \\
& \sum_{k=1}^{k} z_{k}^{t}=1 \quad(\mathrm{VRS}) \\
& z_{k}^{t} \geq 0 \quad k=1, \ldots, K .
\end{aligned}
$$

Therefore, in order to calculate change in scale efficiency under the VRS technology, the contrary output distance functions must also be measured merging equation (6) into the restrictions in equations (8) and (10). Technical change can be measured in relation to the CRS technology. Scale efficiency change in every time period is measured in percentage of the distance function fulfilling CRS in relation to the distance function in VRS. Pure efficiency change on the other side measures the percentage of the own-period distance function in each period in VRS. These two distance functions will break down equation (2) to become: 


$$
\begin{aligned}
M_{o}\left(x^{t}, y^{t},\right. & \left.x^{t+1}, y^{t+1}\right)=\left(\frac{D_{o}^{t+1}\left(x^{t}, y^{t}\right)}{D_{o}^{t}\left(x^{t}, y^{t}\right)}\right)\left(\frac{D_{o}^{t+1}\left(x^{t+1}, y^{t+1}\right)}{D_{o}^{t}\left(x^{t+1}, y^{t+1}\right)}\right)^{\frac{1}{2}} \times\left(\frac{D_{o}^{t}\left(x^{t}, y^{t}\right)}{D_{o}^{t+1}\left(x^{t+1}, y^{t+1}\right)}\right) \\
& \times\left(\frac{D_{o c}^{t+1}\left(x^{t}, y^{t}\right)}{\left.D_{o}^{t+1}\left(x^{t}, y^{t}\right) D_{o}^{t+1}\left(x^{t+1}, y^{t+1}\right) D_{o c}^{t}\left(x^{t+1}, y^{t+1}\right) y^{t}\right) D_{o}^{t}\left(x^{t}, y^{t}\right) D_{o c}^{t}\left(x^{t+1}, y^{t+1}, y^{t+1}\right)}\right)^{\frac{1}{2}}
\end{aligned}
$$

Where

$$
\begin{gathered}
\left(\frac{D_{o}^{t+1}\left(x^{t}, y^{t}\right)}{D_{o}^{t}\left(x^{t}, y^{t}\right)}\right)\left(\frac{D_{o}^{t+1}\left(x^{t+1}, y^{t+1}\right)}{D_{o}^{t}\left(x^{t+1}, y^{t+1}\right)}\right)^{\frac{1}{2}}=\text { Technical Change } \\
\left(\frac{D_{o}^{t}\left(x^{t}, y^{t}\right)}{D_{o}^{t+1}\left(x^{t+1}, y^{t+1}\right)}\right)=\text { Pure efficiency change } \\
\left(\frac{D_{o c}^{t+1}\left(x^{t}, y^{t}\right) D_{o}^{t+1}\left(x^{t+1}, y^{t+1}\right) D_{o c}^{t}\left(x^{t}, y^{t}\right) D_{o}^{t}\left(x^{t+1}, y^{t+1}\right)}{D_{o}^{t+1}\left(x^{t}, y^{t}\right) D_{o c}^{t+1}\left(x^{t+1}, y^{t+1}\right) D_{o}^{t}\left(x^{t}, y^{t}\right) D_{o c}^{t}\left(x^{t+1}, y^{t+1}\right)}\right)^{\frac{1}{2}}=\text { Scale Efficiency change }
\end{gathered}
$$

It is worth to note that if technology in actuality shows CRS, the scale change factor will equal to 1 and it will be equivalent to equation (2).

\section{RESULTS}

The table 1 below is the descriptive statistical analysis of inputs and outputs of Malaysian Islamic banks under study for the period of 2002-2011. The table shows the mean, median, maximum, minimum and the total of both the inputs and outputs. Among the banks, May Bank Islamic has the highest amount of total deposit, capital, total loan, income and investment. This is generally expected given that May Bank is Malaysia's biggest bank and among the early starters of Islamic banking. Affin Islamic Bank has the lowest number of total deposit, capital, total loan, and income, except for investment; where Public Bank Islamic records the lowest figures. Moreover, Table 1 below indicates that over the last nine-year in the sample period (2003-2011), the total maximum loan obtained from the Islamic banking operations from all the five banks increased by $445 \%$. That is, from RM8.25 billion in 2003 to RM45.84 billion in 2011. This indicates that the responsiveness of Malaysians towards the Islamic banking and finance during these years has increased tremendously. During the years (2002-2011), the total maximum income generated from the Islamic banking operations from all the five banks increased from RM264 million in 2003 to RM1.39 billion in 2011. The total income increased by $426 \%$, and this indicates that Islamic banking operations generate substantial amount of income to the banks. This should have significant implication for improved performance of their parent banks.

The maximum total investment in the Islamic banking operations has increased by $113 \%$ from RM2.99 billion in 2003 to RM6.36 billion in 2011. Compared with the percentage increase 


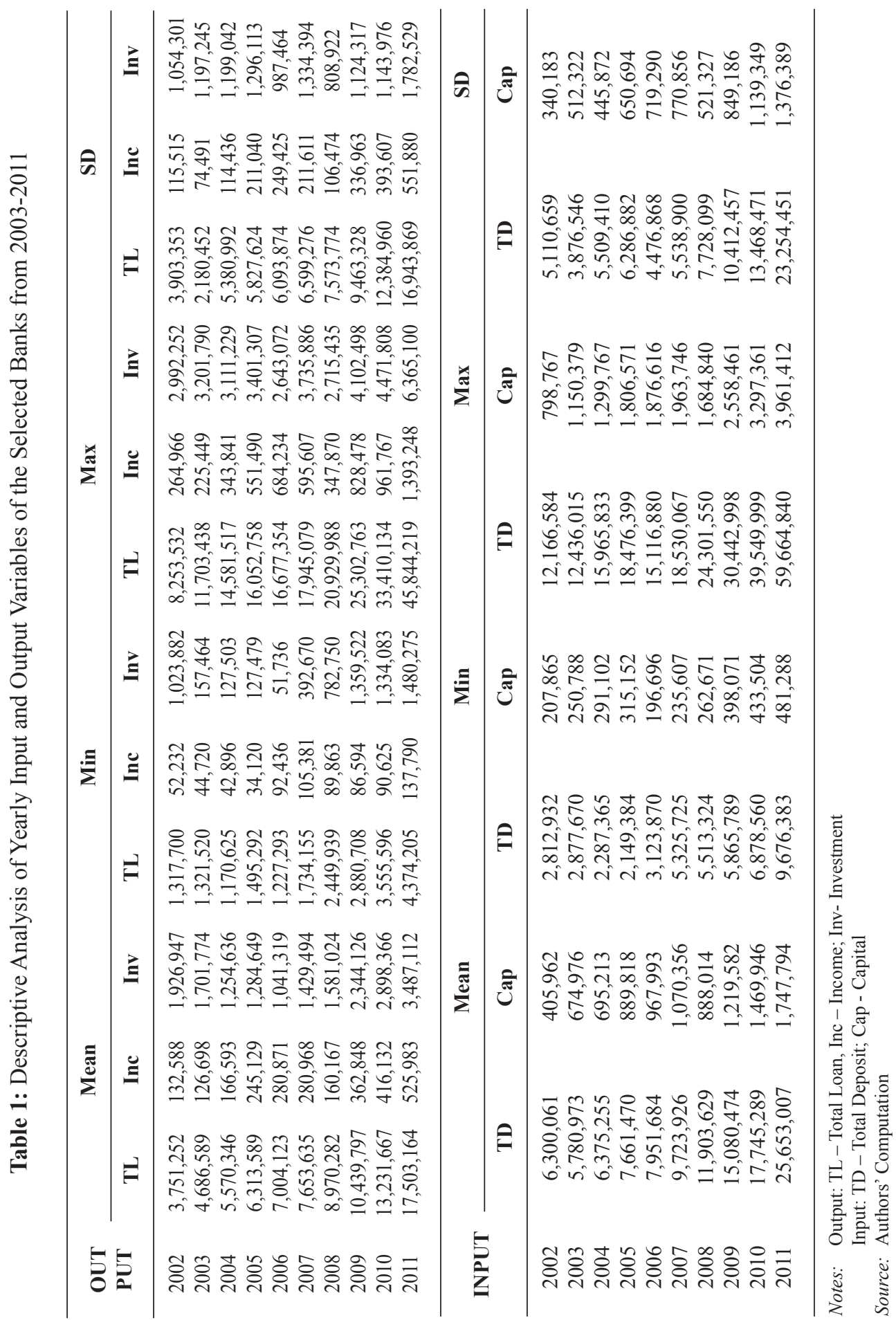


in total income it appears that amount invested quadrupled in returns. This shows income generated from investment is quite high. This is perhaps evidence that Islamic banking and finance is really growing in Malaysia. In addition, the maximum amount of deposits recorded by the banks from 2003 to 2011 increased by 390\%. That is, from RM12.16 billion in 2003 to RM59.66 billion in 2011. This is evidence that the awareness of Islamic banking operations is improving as increase in the total deposits proves more people are patronizing the Islamic banking operations. Finally, the total maximum capital used as start-up capital has increased by $395 \%$ from RM798 million in 2003 to RM3.96 billion in 2011. This shows that banks are expanding their Islamic banking operations such as changing their operation from window to fully fledged Islamic bank as subsidiary to the main bank.

\subsection{Efficiency of the banks, 2003 to 2011 (VRS)}

From Table 2 below, only Hong Leong Islamic Bank is consistently efficient under Variable Return to Scale (VRS). Both Public Islamic Bank and RHB Islamic Bank are found to be efficient under VRS from 2003-2007 and 2008-2011. The banks were only inefficient in the year 2008 under VRS. Whereas, Affin Islamic Bank is found to be efficient under VRS from 2003-2007, and exhibits inefficiency for 2008-2009, the bank is later found to be efficient for 2010-2011. May Bank Islamic is found to be efficient under VRS from year 2003-2005, and the bank result keeps fluctuating. For instance, between 2006 and 2011, the banks oscillate between efficiency and inefficiency every other year. The result shows that majority of the banks have effectively kept pace with precise sufficient production potentials and increased their space to the industrial production frontier under the VRS technology. The only exception in this regard is May Bank Islamic that exhibits inefficiency in 2006.

Table 2: Efficiency of the banks, 2003 to 2011 (VRS)

\begin{tabular}{ccccccccccc}
\hline NO & BANK & $\mathbf{2 0 0 3}$ & $\mathbf{2 0 0 4}$ & $\mathbf{2 0 0 5}$ & $\mathbf{2 0 0 6}$ & $\mathbf{2 0 0 7}$ & $\mathbf{2 0 0 8}$ & $\mathbf{2 0 0 9}$ & $\mathbf{2 0 1 0}$ & $\mathbf{2 0 1 1}$ \\
\hline 1 & AFFIN BANK & 1.000 & 1.000 & 1.000 & 1.000 & 1.000 & 0.733 & 0.966 & 1.000 & 1.000 \\
2 & HONG LEONG BANK & 1.000 & 1.000 & 1.000 & 1.000 & 1.000 & 1.000 & 1.000 & 1.000 & 1.000 \\
3 & MAY BANK & 1.000 & 1.000 & 1.000 & 0.957 & 1.000 & 0.955 & 1.000 & 0.995 & 1.000 \\
4 & PUBLIC BANK & 1.000 & 1.000 & 1.000 & 1.000 & 1.000 & 0.763 & 1.000 & 1.000 & 1.000 \\
5 & RHB BANK & 1.000 & 1.000 & 1.000 & 1.000 & 1.000 & 0.257 & 1.000 & 1.000 & 1.000 \\
\hline & MEAN & 1.000 & 1.000 & 1.000 & 0.991 & 1.000 & 0.742 & 0.993 & 0.999 & 1.000 \\
\hline
\end{tabular}

Source: Authors' Computation

\subsection{Efficiency of the banks, 2003 to 2011 (CRS)}

Also, under the CRS starting from 2004 -2007 majority of the banks are efficient. This indicates that those banks are able to produce $100 \%$ of their potential output during those years prior to starting operations as full-fledged Islamic banks. Again, the only exception is May Bank Islamic that produced $55.2 \%$ of its potential output in 2006. Contrary to the result under VRS in Table 3, most of the banks are found to be inefficient under CRS in Table 4 in 2003. The proportion of their potential output level were Affin Bank 93.5\%, Public Bank 37\% and RHB Bank 48\%. 
Table 3: Efficiency of the banks, 2003 to 2011 (CRS)

\begin{tabular}{ccccccccccc}
\hline NO & BANK & $\mathbf{2 0 0 3}$ & $\mathbf{2 0 0 4}$ & $\mathbf{2 0 0 5}$ & $\mathbf{2 0 0 6}$ & $\mathbf{2 0 0 7}$ & $\mathbf{2 0 0 8}$ & $\mathbf{2 0 0 9}$ & $\mathbf{2 0 1 0}$ & $\mathbf{2 0 1 1}$ \\
\hline 1 & AFFIN BANK & 0.935 & 1.000 & 1.000 & 1.000 & 1.000 & 0.376 & 0.893 & 1.000 & 1.000 \\
2 & HONG LEONG BANK & 1.000 & 1.000 & 1.000 & 1.000 & 1.000 & 1.000 & 1.000 & 1.000 & 0.988 \\
3 & MAYBANK & 1.000 & 1.000 & 1.000 & 0.552 & 1.000 & 0.836 & 1.000 & 0.793 & 1.000 \\
4 & PUBLIC BANK & 0.370 & 1.000 & 1.000 & 1.000 & 1.000 & 0.356 & 0.844 & 1.000 & 1.000 \\
5 & RHB BANK & 0.480 & 1.000 & 1.000 & 1.000 & 1.000 & 0.122 & 1.000 & 1.000 & 1.000 \\
\hline & MEAN & 0.757 & 1.000 & 1.000 & 0.910 & 1.000 & 0.538 & 0.947 & 0.959 & 0.998 \\
\hline
\end{tabular}

Source: Authors' Computation

As shown by the mean scores in Table 3, on average the banks' efficiency increased from 2003 to 2004. The banks were able to maintain this till 2005, experienced a decline in 2006, but increased efficiency again in 2007. If compared with 2008 to 2011, the increase in the overall arithmetic mean before 2008 is better. As exhibited in the arithmetic mean in Table 3, the average efficiency for the banks remained at unity (highly efficient), but declined slightly in 2006. It increased again in 2007 and kept fluctuating after wards. From Tables 2 and 3, the banks' efficiency changed from 2003 to 2011 under the CRS and VRS. This shows that the average efficiency performance of the banks is relatively high from latter perspective. Most of the banks are highly efficient from 2003 to 2007 which is considered as pre-full fledge Islamic banking operations (Islamic window), than during the full fledge Islamic banking operations for both VRS and CRS.

\subsection{Production Performance for Each Bank}

The result shown in Tables 4 to 6 gives the performance of the banks from 2003 to 2011 for changes in TFP and its divisions - Technical Change (TC) and Efficiency Change (EC). The values of the MI TFP productivity index and its division are interpreted as any value that is less than 1 indicates a decrease or deterioration. On the contrary, values that are more than 1 imply development in the relevant area.

The figures shown in the table 4 below indicate average increase or decrease per year for the actual period of time covered. The calculations only focus on performance in relation to the

Table 4: Banks Relative Malmquist TFP Change Between Time Period $t$ and $t+1$, 2003 to 2011

\begin{tabular}{ccccccccccc}
\hline \multirow{2}{*}{ NO } & \multirow{2}{*}{ BANKS } & $\begin{array}{c}\mathbf{2 0 0 3 -} \\
\mathbf{2 0 0 4}\end{array}$ & $\begin{array}{c}\mathbf{2 0 0 4}- \\
\mathbf{2 0 0 5}\end{array}$ & $\begin{array}{c}\mathbf{2 0 0 5 -} \\
\mathbf{2 0 0 6}\end{array}$ & $\begin{array}{c}\mathbf{2 0 0 6}- \\
\mathbf{2 0 0 7}\end{array}$ & $\begin{array}{c}\mathbf{2 0 0 7} \\
\mathbf{2 0 0 8}\end{array}$ & $\begin{array}{c}\mathbf{2 0 0 8}- \\
\mathbf{2 0 0 9}\end{array}$ & $\begin{array}{c}\mathbf{2 0 0 9 -} \\
\mathbf{2 0 1 0}\end{array}$ & $\begin{array}{c}\mathbf{2 0 1 0 -} \\
\mathbf{2 0 1 1}\end{array}$ & MEAN \\
\hline 1 & AFFIN BANK & 1.486 & 1.392 & 1.390 & 2.582 & 2.776 & 1.102 & 0.893 & 1.696 & 1.665 \\
2 & HONG LEONG BANK & 1.712 & 1.264 & 3.091 & 2.798 & 2.715 & 4.091 & 3.786 & 1.330 & 2.598 \\
3 & MAY BANK & 2.269 & 1.141 & 1.290 & 0.848 & 0.725 & 1.336 & 3.846 & 0.666 & 1.515 \\
4 & PUBLIC BANK & 0.543 & 0.883 & 1.193 & 1.639 & 2.038 & 0.362 & 1.426 & 0.938 & 1.128 \\
5 & RHB BANK & 0.947 & 1.678 & 0.634 & 1.202 & 2.864 & 0.412 & 0.887 & 0.586 & 1.151 \\
\hline & MEAN & 1.391 & 1.272 & 1.519 & 1.814 & 2.224 & 1.461 & 2.168 & 1.043 & 1.611 \\
\hline
\end{tabular}

Source: Authors' Computation 
most excellent practice with appropriate performance or rather in relation to the most excellent practice in the sample.

Table 4 exhibits the change in the Malmquist-based TFP index. As shown in Table 5, May Bank, Hong Leong Bank and Affin Banks' performance show a positive productivity changes from 2003 to 2011. On the contrary, Public Bank and RHB Banks' performance shows a highly deteriorating productivity change from 2003 to 2006 and 2008 to 2011. Moreover, Hong Leong Bank has the highest mean of increase in productivity change at an annual average rate of $159 \%$, followed by Affin Bank with annual average mean of $66 \%$ and follow next is May Bank with annual average mean of $55 \%$.

Assessing the whole banks in general, all the banks have increased their productivity change on average by $61 \%$ per annum for the duration 2003 to 2011. The other division of the Malmquist productivity index - Technical Change and Efficiency Change results are reported in Tables 5 and 6 below.

Table 5: Bank Relative Technical Change Between time Period t and t + 1, 2003 - 2011

\begin{tabular}{|c|c|c|c|c|c|c|c|c|c|c|}
\hline NO & BANKS & $\begin{array}{c}2003- \\
2004\end{array}$ & $\begin{array}{l}2004- \\
2005\end{array}$ & $\begin{array}{l}2005- \\
2006\end{array}$ & $\begin{array}{l}2006- \\
2007\end{array}$ & $\begin{array}{c}2007- \\
2008\end{array}$ & $\begin{array}{c}2008- \\
2009\end{array}$ & $\begin{array}{c}2009- \\
2010\end{array}$ & $\begin{array}{c}2010- \\
2011\end{array}$ & MEAN \\
\hline 1 & 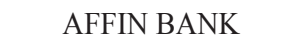 & 0.843 & 0 & 3 & 670 & T & 0.669 & 1.011 & 1.094 & 0.892 \\
\hline 2 & HONG LE & 0.606 & 1.865 & 0.597 & 0.919 & 1.959 & 0.123 & 0.865 & 1.080 & 1.002 \\
\hline 3 & MAY BANK & 0.789 & 0.994 & 1.230 & 0.793 & 1.602 & 0.729 & 0.644 & 1.511 & 1.037 \\
\hline 4 & PUBLIC BANK & 0.747 & 1.109 & 1.373 & 0.782 & 0.651 & 1.683 & 1.272 & 1.723 & 1.168 \\
\hline \multirow[t]{2}{*}{5} & RHB BANK & 0.534 & 0.875 & 1.957 & 1.226 & 1.004 & 0.813 & 1.268 & 2.169 & 1.231 \\
\hline & MEAN & 0.694 & 1.083 & 1.151 & 0.859 & 1.242 & 0.606 & 0.981 & 1.462 & 1.066 \\
\hline
\end{tabular}

Source: Authors' Computation

Table 5 shows the index figures of technical improvement, or decline as calculated by the average changes in the most excellent practice frontier from $t$ to $t+1$. As revealed by the results, all the banks experienced both technical improvement and deterioration from 2003 to 2011. Based on the year under review, Hong Leong Bank has the highest change in technical deterioration of $(-87.7 \%)$ in the year 2008 to 2009 . RHB Bank has the highest technical development $(26.8 \%)$ in the year 2010 to 2011 .

Similarly, Table 5 also presents that all the five banks experienced technical improvement in 2010-2011. The number of banks that are technically improved reduced to three in 2009-2010, while the number drastically declined to one in 2009-2008. The banks that show technical improvement in 2007-2008 are also three. However, in 2006-2007 only one bank out of the five banks experienced technical advancement, four banks in 2005-2006, two banks in 20042005 and no bank experienced technical development in 2003-2004.

Overall average, year 2008-2009 is found to have the highest technical deterioration (-39\%). Affin Bank has the highest technical deterioration (-10.8\%), while RHB Bank has the highest technical improvement with 23.1\% followed by Public Bank with $16.8 \%$, May Bank is found to have $3.7 \%$ and Hong Leong Bank with $0.2 \%$. 
Table 6: Changes in Banks Relative Efficiency between Time Period t and $t+1$, 2003 to 2011

\begin{tabular}{|c|c|c|c|c|c|c|c|c|c|c|}
\hline NO & BANKS & $\begin{array}{l}2003- \\
2004\end{array}$ & $\begin{array}{c}2004- \\
2005\end{array}$ & $\begin{array}{l}2005- \\
2006\end{array}$ & $\begin{array}{l}2006- \\
2007\end{array}$ & $\begin{array}{c}2007- \\
2008\end{array}$ & $\begin{array}{c}2008- \\
2009\end{array}$ & $\begin{array}{c}2009- \\
2010\end{array}$ & $\begin{array}{l}2010- \\
2011\end{array}$ & MEAN \\
\hline 1 & IN BANK & .069 & 0 & 1.000 & 1.000 & 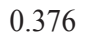 & 76 & 20 & 000 & 1.118 \\
\hline 2 & HONG LEONG BANK & 1.000 & 1.000 & 1.000 & 1.000 & 1.000 & 1.000 & 1.000 & 0.988 & 0.999 \\
\hline 3 & MAY BANK & 1.000 & 1.000 & 0.552 & 1.813 & 0.836 & 1.196 & 0.793 & 1.262 & 1.057 \\
\hline 4 & PUBLIC BANK & 2.704 & 1.000 & 1.000 & 1.000 & 0.356 & 2.369 & 1.185 & 1.000 & 1.327 \\
\hline \multirow[t]{2}{*}{5} & RHB BANK & 2.083 & 1.000 & 1.000 & 1.000 & 0.122 & 8.175 & 1.000 & 1.000 & 1.923 \\
\hline & MEAN & 1.432 & 1.000 & 0.888 & 1.126 & 0.424 & 2.229 & 1.010 & 1.045 & 1.284 \\
\hline
\end{tabular}

Source: Authors' Computation

\section{FINDINGS}

Result from Table 6 presents the relative change efficiency for each bank. The findings show the significant difference among the banks and periods. Most of the banks are found to be efficient from 2004 to 2007. A plausible reason could be the global financial crisis that became pervasive since around 2008. As noted by Derbel, Bouraoui \& Dammak (2011), the Islamic banking and finance industry was also mildly affected by the crisis as reflected in their relatively dismal performance during the period. As such, for the rest of the years the banks experienced fluctuation in their efficiency; that is the efficiency increased more than 1 in some period, and less than 1 in some other period or the efficiency remained constant - that is no changes in efficiency.

In addition, the findings revealed that majority of the banks have constant efficiency from 2004-2007. During this period most of the banks operated their Islamic banking operations as a window within their parent banks. The reason for this could be to some extent that the operations of the conventional banking operated side-by-side with the Islamic banking operations thereby supporting the efficiency of the Islamic window. There is also a possibility that the activities of the conventional banking operations significantly increase or stabilize the Islamic banking operations during those periods. It could be that conventional banking operations help Islamic banking operation in areas such as loans and advances, capital market investment and money market investment since both banking operations will at the end of the year report a single financial report. Moreover, Samad (2009) noted that the Islamic banking windows demonstrate efficiency if they could leverage on the operational efficiency of the existing conventional banking arrangements within their banks.

It is likely that the motive for running both banking operations (conventional and Islamic) is to generate more returns to the banks. As such, it can be argued that efficiency is maintained during those periods because the banks appear to be able to reduce their personnel and capital expenses. For instance, same staffs that are used to operate the conventional banking operations also operate the Islamic banking operations. This, perhaps save the banks some money, unlike when they operate as a full fledge Islamic bank, in which case as a subsidiary their operations is totally separated from the conventional banking system. This aligns with the opinion of Berger 
and Humphrey (2007) and Hassan et al (2009) that attribute the Islamic banking windows' efficiency to shared cost of input like personnel and administrative expenses.

More so, efficiency can also be maintained due to capital expenditure - the capital expenditure was borne by the whole bank not the Islamic window. For example: building rent, electricity bill and other maintenance expenses. All the expenses will not affect the operation of the Islamic window thus they will be efficient since the input will be low in terms of expenses and output is maximized. Based on the years under examination, this study findings show that, RHB Bank has the highest level of efficiency change with 92.3\%, Public Bank takes second position by recording 32.7\%, the next is Affin Bank with 11.8\%, followed by May Bank with $5.7 \%$ and Hong Leong Bank is found to be the only bank that experienced efficiency deterioration with $(-0.1 \%)$. This is notwithstanding the fact that Public Bank has the highest level of efficiency deterioration during the year 2007 to 2008 with (-64.4\%). Generally, ranging from 2003 to 2011, with exception of 2007 to 2008 with the least record of positive efficiency change follow by 2005 to 2006, all other years present a positive efficiency change.

Moreover, the pure efficiency seems not to be significant means of growth to efficiency change, if compared with the scale efficiency change division for each bank under review. Except for Hong Leong Bank, the other banks under examination experienced changes in both pure efficiency and scale efficiency during the year 2007 to 2008 and 2008 to 2009. Such findings align with those of Mokhtar, Abdullah \& Alhabshi (2008) and Sufian (2006). They stated that a likely reason could be because this period marks the year when most of the banks changed their operations from Islamic window to full fledge Islamic banking.

All the banks recorded positive changes in their yearly growth for pure efficiencies from 2003 to 2007, except May Bank that experienced decline in efficiency with about (-4.3\%) in 2005 and experienced efficiency improvement of about 4.4\% in 2006. RHB Bank has the highest deterioration of pure efficiency of $(-74.3 \%)$ in 2007 to 2008. Public Bank has the highest deterioration of (-53.3\%) in 2007 to 2008 in terms of scale efficiency. Interestingly, RHB Bank has the highest improvement of pure efficiency of $288 \%$ in year 2008 to 2009. Public Bank on the other hand also has the highest improvement of scale efficiency of $108 \%$ in year 2003 to 2004. For the entire years under examination, year 2008 to 2009 is recognized as the year of pure efficiency advancement. While the rest of the period, is recognized as years of scale efficiency improvement.

\section{CONCLUSION}

This study compared the efficiency of five Islamic banks in Malaysia during their operation as Islamic window and later transformation to a full-fledged Islamic bank. The aim is to fill an apparent dearth of empirical studies in this context, especially in the case of Malaysia as a hub of the burgeoning Islamic banking and finance industry. Data envelopment analysis is used to assess both the technical and scale efficiency of the banks under sample. Sequel to the results obtained the following conclusion is made in this study.

From the analysis in this study, the efficiency scores for the bank as an Islamic window are relatively better compared to subsequent efficiency scores obtained for same Islamic banks 
as a full-fledged subsidiary. As such, a conclusion may be that Islamic windows are more efficient than full fledge Islamic bank.

Moreover, year of commencement of operation seems to exert so much influence on efficiency at least in the context of the Islamic banks under sample. Based on this study's analysis, banks that have longer years of operation of Islamic banking and finance as windows (May Bank and Public Bank) are more efficient compared with banks that started full fledge Islamic banking early (RHB Bank and Affin Bank). Therefore, this study can conclude that years of existence determine efficiency.

Based on the summary of the MI productivity means of the banks; it is indicated that the Total Productivity Change has been improved over the years covered. However, it will be important to point out here that the improvement in the Total Productivity Change is as a result of increase in both technical change and efficiency change, and with the latter enjoying prominence. It is thus concluded that Islamic banks should leverage more on technological knowledge to be able to optimize the technical procedure so as to enable them increase their competitive edge in the future.

\section{REFERENCES}

Abdul-Majid, M., Saal, D. S., \& Battisti, G. (2011). The impact of Islamic banking on the cost efficiency and productivity change of Malaysian commercial banks. Applied Economics, 43(16), 2033-2054.

Afriat, S. N. (1972). Efficiency estimation of production functions. International Economic Review, 13(3), 568-598.

Akhtar, M. H. (2010). Technical Efficiency and Productivity Growth of Saudi Banks A Data Envelopment Analysis Approach. Global Business Review, 11(2), 119-133.

Alam, I. M. S., \& Sickles, R. C. (1997). Long run properties of technical efficiency in the US airline industry. Wissenschaftszentrum Berlin Für Sozialforschung, FS IV 97 - 25.

Avkiran, N. K. (2001). Investigating technical and scale efficiencies of Australian universities through data envelopment analysis. Socio-Economic Planning Sciences, 35(1), 57-80.

Bader, M. K. I., Mohamad, S., Ariff, M., \& Hassan, T. (2008). Cost, revenue and profit efficiency of Islamic versus conventional banks: international evidence using data envelopment analysis. Islamic Economic Studies, 15(2), 23-76.

Bank Negara Malaysia. (2012). List of Licensed Banking Institutions in Malaysia. Retrieved January 1, 2013, from http://www.bnm.gov.my/index.php?ch=li\&cat=islamic\&type=IB \& fund $=0 \& \mathrm{cu}=0$ 
Barry Porter (2012). IILM Plans First Islamic Dollar Bill Sale of Up to \$1 Billion. Retrieved January 1, 2013, from http://www.bloomberg.com/news/2012-03-21/iilm-plans-firstislamic-dollar-bill-sale-of-up-to-1-billion.html

Berger, A. N., \& Humphrey, D. B. (1997). Efficiency of financial institutions: International survey and directions for future research. European journal of operational research, 98(2), 175-212.

Calabrese, A., Campisi, D., \& Mancuso, P. (2002). Productivity change in the telecommunications industries of 13 OECD countries. International Journal of Business and Economics, 1(3), 209-223.

Coelli, T. (1996). A guide to DEAP version 2.1: a data envelopment analysis (computer) program. CEPA working paper 96/08.

Derbel, H., Bouraoui, T., \& Dammak, N. (2011). Can Islamic Finance Constitute A Solution to Crisis? International Journal of Economics and Finance, 3(3), 75-83.

Färe, R., Grosskopf, S., \& Roos, P. (1998). Malmquist productivity indexes: a survey of theory and practice. Index numbers: Essays in honour of Sten Malmquist, 1(2), 127-190.

Färe, R., Grosskopf, S., Norris, M., \& Zhang, Z. (1994). Productivity growth, technical progress, and efficiency change in industrialized countries. The American Economic Review, 66-83.

Favero, C. A., \& Papi, L. (1995). Technical efficiency and scale efficiency in the Italian banking sector: a non-parametric approach. Applied Economics, 27(4), 385-395.

Hasan, I., Koetter, M., \& Wedow, M. (2009). Regional growth and finance in Europe: Is there a quality effect of bank efficiency? Journal of Banking \& Finance, 33(8), 1446-1453.

Hasan, Z. (2005). Evaluation of Islamic banking performance: On the current use of econometric models. MPRA Paper No. 6461.

Hassan, M. K., \& Hussein, K. A. (2003). Static and dynamic efficiency in the Sudanese banking system. Review of Islamic Economics, 14, 5-48.

Hassan, T., Mohamad, S., \& Bader, M. K. I. (2009). Efficiency of conventional versus Islamic banks: evidence from the Middle East. International Journal of Islamic and Middle Eastern Finance and Management, 2(1), 46-65.

Koo, W., \& Mao, W. (1996). Productivity growth, technology progress, and efficiency change in Chinese agricultural production from 1984 to 1993. Agricultural Economics Report No. 362. 
Kwan, S. H. (2003). Operating performance of banks among Asian economies: An international and time series comparison. Journal of Banking \& Finance, 27(3), 471-489.

Laldin, M. A. (2008). Islamic financial system: the Malaysian experience and the way forward. Humanomics, 24(3), 217-238.

Mlima, A. P., \& Hjalmarsson, L. (2002). Measurement of inputs and outputs in the banking industry. Tanzanet Journal, 3(1), 12-22.

Mohamad, S., Hassan, T., \& Bader, M. K. I. (2008). Efficiency of conventional versus Islamic Banks: international evidence using the Stochastic Frontier Approach (SFA). Journal of Islamic Economics, Banking and Finance, 4(2), 107-130.

Mokhtar, H. S. A., Abdullah, N., \& Al-Habshi, S. M. (2006). Efficiency of Islamic banking in Malaysia: A stochastic frontier approach. Journal of Economic Cooperation, 27(2), $37-70$.

Mokhtar, H. S. A., Abdullah, N., \& Alhabshi, S. M. (2008). Efficiency and competition of Islamic banking in Malaysia. Humanomics, 24(1), 28-48.

Rafiuddin, A., \& Alam, Z. (2012). Islamic Banks and Conventional Banks in The UAE Before and After Recession. International Journal of Finance Management, 1(1), 70-79.

Rashwan, M. (2010). A comparison between Islamic and traditional banks: Pre and post the 2008 financial crisis. Retrieved January 1, 2013, from http:// http://papers.ssrn.com/ sol3/papers.cfm?abstract_id=1724451.

Samad, A. (2004). Performance of interest-free Islamic banks vis-à-vis interest-based conventional banks of Bahrain. IIUM Journal of Economics and Management, 12(2), $1-15$.

Samad, A. (2009). Comparative efficiency of the Islamic bank vis-à-vis conventional banks in Malaysia. IIUM Journal of Economics and Management, 7(1), 1-27.

Sealey, C., \& Lindley, J. (1977). Inputs, Outputs and a Theory of Production and Cost at Deposit. The Journal of Finance, 32(4), 1251-1266.

Sufian, F. (2006). Size and returns to scale of the Islamic banking industry in Malaysia: foreign versus domestic banks. IIUM Journal of Economics and Management, 14(2), 147-175.

Sufian, F. (2007a). The efficiency of Islamic banking industry in Malaysia: Foreign vs domestic banks. Humanomics, 23(3), 174-192.

Sufian, F. (2007b). The efficiency of Islamic banking industry: A non-parametric analysis with non-discretionary input variable. Islamic Economic Studies, 14(1-2), 53-78. 
Sufian, F., \& Haron, R. (2009). On the efficiency of the Malaysian banking sector: a risk-return perspective. International Journal of Commerce and Management, 19(3), 222-232.

Sufian, F., \& Noor, M. A. N. M. (2009). The determinants of Islamic banks' efficiency changes: Empirical evidence from the MENA and Asian banking sectors. International Journal of Islamic and Middle Eastern Finance and Management, 2(2), 120-138.

Tauer, L. W., \& Lordkipanidze, N. (1999). Productivity of dairy production in individual States. Department of Agricultural, Resource, and Managerial Economics, Cornell University Working Paper No. 99-08.

Wahab, N. A., \& Rahman, A. R. A. (2012). Efficiency of zakat institutions in Malaysia: An application of data envelopment analysis. Journal of Economic Cooperation and Development, 33(1), 95-112. 